\title{
Uncomfortable bite - is it always a dental problem?
}

\section{Niekomfortowy zgryz - czy zawsze jest to problem stomatologiczny?}

\author{
Jolanta Kostrzewa-Janicka \\ Katedra Protetyki Stomatologicznej, Warszawski Uniwersytet Medyczny \\ Department of Prosthodontics, Medical University of Warsaw \\ Head: prof. dr hab. n. med. Elżbieta Mierzwińska-Nastalska
}

KEY WORDS:

occlusal dysesthesia, occlusion hyperawareness, somatoform disorders, occusal neurosis

Abstract

Subjective symptoms of uncomfortable bite that are not reflected during a clinical examination are termed occlusal dysesthesia or phantom bite. The unclear aetiology and pathophysiology of this phenomenon causes huge diagnostic and therapeutic problems. Severe symptoms of an uncomfortable bite provoke a number of corrections of the occlusion, which fail to bring improvement and even exacerbate the already existing symptoms. For this reason, the analysis of the literature on occlusal dysesthesia during the past twenty years has been performed. From among 43 articles from the medical databases of PubMed and Scopus in 1997 and 2017, five papers were included based on the adopted inclusion and exclusion criteria. Based on the available research, it is recommended to discontinue any invasive dental procedures in cases of confirmed occlusal dysesthesia symptoms, including correction and reconstruction of the bite. Instead, patient education, pharmacological treatment or the use of relaxation occlusal splints should be implemented. The studies indicate that the occurrence of symptoms of occlusal dysesthesia is correlated with the general condition of the patient, their somatic and psycho-emotional disorders. Interference in occlusal conditions can cause additional injury and potentially result in iatrogenic complications.

\section{HASŁA INDEKSOWE:}

dysestezja okluzyjna, nadwrażliwość okluzyjna, schorzenia somatyczne, nerwica okluzyjna

Streszczenie
Subiektywne objawy niekomfortowe-
go zgryzu, które nie maja odzwierciedle-
nia w klinicznym badaniu określane sa, jako
dysestezja okluzyjna lub zgryz fantomowy.
Niejasna etiologia oraz patofizjologia tego zja-
wiska sprawia ogromne problemy diagnostyczne
i lecznicze. Drastyczne objawy niekomfortowe-
go zgryzu prowokuja wiele korekt zwarcia, które
nie przynosza poprawy, a sa przyczyna nasilenia
objawów. Z tego powodu, wykonano analize pi-
śmiennictwa, dotyczacego dysestezji okluzyjnej
w ciagu 20-stu ostatnich lat. Spośród 43 arty-
kułów z medycznych baz PubMed i Scopus w la-
tach 1997 a 2017 właczono 5 prac na podstawie
przyjętych kryteriów wtaczenia i wykluczenia.
Na podstawie dostepnych badań, wskazane jest
abyw przypadkach stwierdzonych objawów dyse-
stezji okluzyjnej zaniechaćjakichkolwiek inwazyj-
nych procedur stomatologicznych, obejmujacych
korektę i rekonstrukcję zwarcia. Zaleca się wdro-
zenie edukacji pacjenta, leczenia farmakologicz-
nego lub zastosowanie relaksacyjnych szyn zgry-
zowych. Badania wskazuja bowiem na zależność
wystapienia objawów dysestezji okluzyjnej od
stanu ogólnego pacjenta: schorzeń somatycznych
i psycho-emocjonalnych. Ingerencja w warunki
zwarciowe może stać się przyczyna dodatkowego
urazu i być powodem jatrogennych powikłań.




\section{Introduction}

Feeling of an "uncomfortable bite" without the signs of trauma presents a diagnostic and therapeutic challenge. This condition is referred to as occlusal dysesthesia, phantom bite, or occlusal neurosis. ${ }^{1-4}$ Ailments almost always start to occur after dental procedures that have interfered with the occlusion. The symptoms of dysesthesia may occur after bite reconstruction and orthodontic treatment. They may also be caused by a change resulting from one prosthetic crown or a single tooth extraction. Then the patient begins to report problems: the lack of maximum interocclusal contact and the condition commonly referred to as "uncomfortable bite". Many attemped corrections not only fail to bring the expected improvement, but it is the cause of deterioration of the patient's condition and exacerbation of discomfort.

Determination if the patient is suffering from occlusal dysesthesia is difficult at the beginning of dental treatment. However, there are procedures that can be used to signal the problem and indicate failures associated with the acceptance of a new occlusion, especially that the influence of psychiatric factors on the possibility of this type of discomfort is well recognized. ${ }^{5}$

\section{The aim of the study}

The aim of the study was to review the original research, which deals with the subject of the occurrence of subjective ailments within the bite without the features of traumatic occlusion in clinical examination.

\section{Material and methods}

Articles that appeared in the time range 1997-2017 and are available in medical databases: PubMed and Scopus were

\section{Wstęp}

Odczuwanie „niekomfortowego zgryzu” bez przedmiotowych oznak zgryzu urazowego sprawia wiele problemów diagnostyczno-leczniczych. Stan ten jest określany mianem dyzestezji okluzyjnej (ang. occlusal dysesthesia), zgryzu fantomowego, lub nerwicy okluzyjnej. ${ }^{1-4}$ Dolegliwości prawie zawsze rozpoczynają się po procedurach stomatologicznych, które ingerują w zgryz. Objawy dyzestezji mogą pojawić się po rekonstrukcjach zwarcia czy leczeniu ortodontycznym. Może je również wywołać zmiana, którą spowoduje wykonanie jednej protetycznej korony, czy pojedyncza ekstrakcja zęba. Wtedy pacjent zaczyna zgłaszać problemy: brak możliwości maksymalnego zwarcia zębów i ogólnie określany „,niekomfortowy zgryz". Wiele wykonanych korekt nie tylko nie przynosi oczekiwanej poprawy, ale jest przyczyną pogorszenia stanu pacjenta i nasilenia dolegliwości.

Trudno jest na początku leczenia stomatologicznego stwierdzić, czy pacjent cierpi na dyzestezję okluzyjną. Są jednak procedury, których zastosowanie może zasygnalizować problem i wskazać na niepowodzenia związane $\mathrm{z}$ akceptacją nowego zwarcia. Tym bardziej, że na możliwość wystąpienia tego typu dolegliwości stwierdzany jest wpływ czynników psychiatrycznych. ${ }^{5}$

\section{Cel pracy}

Celem pracy był przegląd oryginalnych badań, które poruszają temat występowania subiektywnych dolegliwości w obrębie zgryzu bez przedmiotowych cech zwarcia urazowego.

\section{Material i metody}

Dokonano przeglądu artykułów, które ukazały się w przedziale czasowym 1997-2017 i są dostępne w medycznych bazach: PubMed oraz 
reviewed. The following search terms were used: "occlusal dysesthesia, occlusion hyperwarness, somatoform disorders, occusal neurosis". Exclusion criteria were as follows: case reports, systematic reviews, review works and non-randomized research work. A total of forty-three articles were found, of which, after evaluation of the titles and abstracts, four original works were selected, meeting the predetermined inclusion criteria. ${ }^{6-9}$ While reviewing the reference literature of selected articles, one more work was qualified. ${ }^{10}$

\section{Results}

It has been shown that people with occlusal dysesthesia have the same ability to recognize interdental thickness discrimination ability as healthy people, but achieve higher scores of psychosomatic problems. ${ }^{6}$ The research studies involved the use of an interdental thickness discrimination test between the teeth, including the chewing of standard 2, 5, and $10 \mathrm{~mm}$ thick blocks and 12 test blocks: thinner and thicker than the standard ones, as well as psychological tests: General Health Assessment Test Questionnaire, GHQ60 and Profile of Mood States, POMS. There was no statistically significant difference in the ability to recognize the particle size between the teeth in people with or without occlusal dysesthesia. Also, in relation to psychological tests there was no statistically significant difference in the overall assessment of the study group and the control group. However, a statistically significant difference was found between the groups in the evaluation of several subscales referring to "somatic symptoms". The conclusion was drawn that people with symptoms of occlusal dysesthesia tend to declare higher scores in assessing psychosomatic suffering.

The results obtained by Baba et al. ${ }^{10}$ support the research regarding the differentiation of particle size between teeth. They showed that
Scopus. Zastosowano następujące hasła wyszukiwania: „occlusal dysesthesia, occlusion hyperwarness, somatoform disorders, occusal neurosis". Kryteria wyłączenia prac z analizy obejmowały: opisy przypadków, przeglądy systematyczne, prace poglądowe oraz nierandomizowane prace badawcze. Znaleziono 43 artykuły, z których po ocenie tytułów i streszczeń wyodrębniono 4 oryginalne prace, spełniające ustalone kryteria włączenia. ${ }^{6-9}$ Przeglądając piśmiennictwo wybranych artykułów zakwalifikowano jeszcze jedną pracę. ${ }^{10}$

\section{Wyniki}

Wykazano, że osoby z dyzestezją okluzyjną mają taką sama zdolność rozpoznawania przeszkód zwarciowych jak osoby zdrowe, ale osiągają wyższe wyniki oceny problemów psychosomatycznych. ${ }^{6}$ Omawiane badania polegały na zastosowaniu testu rozpoznawania wielkości cząstek między zębami, obejmującego żucie standardowych bloczków o 2, 5, i $10 \mathrm{~mm}$ grubości i 12 bloczków testowych: cieńszych oraz grubszych od standardowych a także testów psychologicznych: Testu Oceny Zdrowia Ogólnego (ang. General Health Questionnaire, GHQ60) i Profiu Nastrojów (ang. Profile of Mood States, POMS). Nie wykazano istotnej statystycznie różnicy w zdolności rozpoznawania wielkości cząstek między zębami u osób bez i z dyzestezją okluzyjną. Również w odniesieniu do testów psychologicznych nie zaobserwowano statystycznie istotnej różnicy w ogólnej ocenie badanej grupy i grupy kontrolnej. Jednakże zaobserwowano istotną statystycznie różnicę między grupami $\mathrm{w}$ ocenie kilku podgrup testów, odnoszących się do „objawów somatycznych”. Wyciągnięto wniosek, że osoby z objawami dyzestezji okluzyjnej wykazują tendencję do uzyskiwania większych punktów w ocenie cierpienia psychosomatycznego.

Poparciem wyników, dotyczących rozróżniania wielkości cząstek między zębami są 
people with diagnosed occlusal dysesthesia were able to feel smaller particles than healthy people do (8 microns vs. 14 microns); however, it was statistically insignificant.

The results of studies of other authors ${ }^{7}$ indicate that the treatment of patients with symptoms of occlusal dysesthesia should consider the possibility of psychiatric disorders that may indicate physical complaints. Patients with symptoms of occlusal dysesthesia were examined in the aspect of their psychosomatic evaluation and approach to the adopted treatment. The patients were divided into groups including: improvement, discontinuation of treatment, change of medical clinics. More than $30 \%$ of patients reported interruption of treatment, and over $20 \%$ of subjects were referred to other counseling centers, mainly psychiatric ones. However, in $5 \%$ of patients interruption and resumption of treatment after 3 months, 2 or 5 years were observed. In patients who discontinued treatment, various types of mental disorders and diseases were found. Hence the suggestion that people showing signs of occlusal dysesthesia should be examined for those psychiatric conditions that manifest physical symptoms but not revealed during physical examination.

Narita et al. ${ }^{8}$ also confirmed strong somatization in patients with symptoms of dysesthesia. The test methods included evaluation of occlusal contacts, masticatory muscles activity, imaging of the prefrontal cortex hemodynamics (used to assess the mental state of patients with mental disorders) and the use of the Symptom Checklist-90-R (SCL90-R) test. Deactivation of the prefrontal cortex during chewing and strong somatization have been demonstrated in patients with symptoms of occlusal dysesthesia.

The results obtained by Ono et al. in $2016^{9}$ confirm the difference in the hemodynamic activity of the prefrontal cortex between individuals with diagnosed occlusal dysesthesia dane uzyskane przez Babę i wsp. ${ }^{10}$ Wykazali oni, że osoby z rozpoznaną dyzestezją okluzyjną czuli mniejsze wielkości niż osoby zdrowe (8 mikronów vs 14 mikronów), jednak nie była to różnica istotna statystycznie.

Wyniki badań innych autorów ${ }^{7}$ wskazują, że lecząc pacjentów z objawami dyzestezji okluzyjnej należy rozważyć możliwość występowania zaburzeń psychicznych, które mogą wskazywać na dolegliwości fizyczne. Pacjenci z objawami dyzestezji okluzyjnej zostali zbadani $\mathrm{w}$ aspekcie ich oceny psychosomatycznej oraz podejścia do zastosowanego leczenia. Pacjenci zostali podzieleni na grupy obejmujące: poprawę, przerwanie leczenia, zmianę poradni medycznych. U ponad 30\% pacjentów stwierdzono przerwanie leczenia, zaś ponad $20 \%$ badanych skierowano do innych poradni, głównie psychiatrycznych. Natomiast u 5\% pacjentów zaobserwowano przerwanie i ponowne podjęcie leczenia po okresie 3 miesięcy, 2 lub 5 lat. U pacjentów, którzy przerwali leczenie stwierdzono różne typy zaburzeń i chorób psychicznych. Stąd sugestia, że osoby wykazujące objawy dyzestezji okluzyjnej należy zbadać w kierunku schorzeń psychiatrycznych, manifestujących objawy fizyczne, które nie są stwierdzane podczas badania przedmiotowego.

Narita i wsp. ${ }^{8}$ również potwierdzili silną somatyzację u pacjentów z objawami dyzestezji. Metody badań obejmowały ocenę kontaktów okluzyjnych, aktywności mięśni żucia, obrazowanie połączeń naczyniowo-nerwowych kory mózgowej przedczołowej (stosowane do oceny stanu psychicznego pacjentów z zaburzeniami psychicznymi) oraz zastosowanie testu Symptom Checklist-90-R (SCL-90-R). Wykazano dezaktywację kory przedczołowej w trakcie żucia i silną somatyzację u pacjentów z objawami dysestezji okluzyjnej.

Wyniki uzyskane przez Ono i wsp. z 2016 $\mathrm{roku}^{9}$ potwierdzają różnicę $\mathrm{w}$ hemodynamicznej aktywności kory przedczołowej między osobami ze stwierdzoną dyzestezją a osobami 
(OD) and healthy people during chewing. Six patients with OD (group OD) and eight patients without OD (the controls) had the occlusal strips placed between the first molars. Patients reported their perception and discomfort resulting from chewing of strips of a particular size while the hemodynamic activity of their prefrontal cortex was continuously monitored with a portable fuctional near-infrared spectroscopy. Patients without OD showed a typical haemodynamic pattern of increased oxyhaemoglobin concentration and decreased deoxyhemoglobin $(\mathrm{HHb})$ concentration, and subjects with OD showed a sustained increase in $\mathrm{HHb}$ concentration that started when occlusal strips were inserted on their molars prior to chewing. The intensity of activities related to the level of $\mathrm{HHb}$ showed statistically significant differences between the OD group and the controls.

Activity of the prefrontal cortex may, therefore, be identified as a characteristic neurological feature of patients with occlusal dysesthesia.

\section{Discussion}

Occlusal dysesthesia is a rare condition that manifests itself mainly in uncomfortable bite without obvious clinical signs of trauma. 1,3,4 The condition is mainly reported in women, as are symptoms of temporomandibular disorders, of which about $30 \%$ have discomfort associated with occlusion. ${ }^{11}$ The lack of official classification of this condition, as well as the explanation of etiology and pathophysiology, makes the management of this group of patients difficult for physicians in their daily practice. This is especially important when a significant bite reconstruction is planned due to a generalized pathological tooth wear, malocclusions exacerbated by missing teeth, or for aesthetic reasons. One should bear in mind the drastic subjective symptoms associated with zdrowymi podczas żucia. Sześciu pacjentów z DO (grupa DO) i ośmiu pacjentów bez DO (grupa kontrolna) żuło paski umieszczone pomiędzy pierwszymi zębami trzonowymi. Pacjenci zgłaszali swoje postrzeganie i dyskomfort, wynikający z żucia określonego wymiaru pasków, podczas ciągłego monitorowania aktywności hemodynamicznej ich kory przedczołowej za pomocą przenośnej funkcjonalnej spektroskopii w bliskiej podczerwieni. Pacjenci bez DO wykazywali typowy hemodynamiczny wzorzec zwiększonego stężenia oksyhemoglobiny i obniżone stężenie deoksyhemoglobiny (HHb), a osoby z DO wykazywały trwały wzrost stężenia $\mathrm{HHb}$, który rozpoczął się przy układaniu pasków okluzyjnych na ich zęby trzonowe, przed wykonaniem aktu żucia. Intensywność czynności związanych z poziomem $\mathrm{HHb}$ wykazała istotne statystycznie różnice między grupą DO a grupą kontrolną.

Aktywność kory przedczołowej może więc się okazać charakterystyczną cechą neurologiczną pacjentów z dyzestezją okluzyjną.

\section{Dyskusja}

Dyzestezja okluzyjna jest rzadkim stanem, który objawia się głównie dolegliwościami związanymi z niekomfortowym zgryzem bez oczywistych oznak klinicznych zgryzu urazowego. ${ }^{1,3,4}$ Schorzenie to głównie występuje u kobiet, podobnie jak objawy schorzeń skroniowo-żuchwowych, wśród których u około $30 \%$ stwierdzany jest dyskomfort związany ze zgryzem. ${ }^{11}$ Brak oficjalnej klasyfikacji tego stanu, podobnie jak wyjaśnienie etiologii i patofizjologii, utrudnia lekarzom w codziennej praktyce postępowanie $\mathrm{z}$ tą grupą pacjentów. Jest to szczególnie ważne, gdy planowana jest znaczna rekonstrukcja zwarcia z powodu uogólnionego patologicznego starcia zębów, wad zgryzu pogłębionych brakami w uzębieniu lub ze względów estetycznych. Należy mieć na 
the new "uncomfortable occlusion", irritation of the patient due to lack of improvement after repeated adjustments, or even worsening or complications resulting from many attempts to reproduce "a perfect occlusion".

There are several hypotheses that attempt to explain the aetiology of this problem. Both psychopathology, phantom bite and impaired proprioception in the stomatognathic system are considered. ${ }^{1,3,11}$ Marbach $^{1}$ suggested a psychological aetiology that qualified this disorder as monosomptomatic hypochondrical psychosis, where the single symptom was the feeling of malocclusion. The condition was classified as somatic delusional disease. Clark and Simmons ${ }^{11}$ upheld the theory proposed by Marback ${ }^{1}$ and emphasized the impact of somatic disorders on the emergence of dysesthesia. Other authors questioned its validity, for example studies by Watanabe et al. indicated that less than $50 \%$ of patients with occlusal dysesthesia had been diagnosed with a mental illness. ${ }^{12}$

Further development of aetiological theories pointed to the possibility of transferring to dentistry the theory of neuro-signature, located in the matrix of neurons of the central nervous system, which contains information about the whole body. ${ }^{2}$ When the neuro-signature of a patient's bite does not agree with the information about bite that dental treatment has modified, it can lead to symptoms of occlusal dysesthesia in people with certain predispositions. This is comparable with the phantom pain of an amputated limb and the lack of adaptation to a prosthesis. In dentistry we encounter a similar phenomenon, when new occlusal contacts are not recognized as patient's "own-bite".

Another aetiological theory proposed by Clark and Simmons ${ }^{11}$ indicates impaired proprioception. According to this theory, altered mandibular position changes the ability to distinguish particles between teeth. However, the results of studies by other authors ${ }^{6,7}$ do not uwadze drastyczne subiektywne objawy związane z nowym ,niekomfortowym zgryzem”, irytację pacjenta $\mathrm{z}$ powodu braku poprawy po wielokrotnych korektach, a wręcz pogorszenie lub powikłania, wynikające $\mathrm{z}$ wielu prób odtworzenia ,idealnej okluzji”.

Istnieje kilka hipotez, próbujących wyjaśnić etiologię tego problemu. Rozważa się zarówno psychopatologię, zgryz fantomowy, jak i zaburzoną propriocepcję w układzie stomatognatycznym. ${ }^{1,3,11}$ Marbach $^{1}$ zasugerował etiologię psychologiczną, która kwalifikowała to schorzenie jako monosymptomatologiczną psychozę hipochondryczną (ang. monosymptomatic hypochondrical psychosis), gdzie pojedynczym objawem było poczucie nieprawidłowego zgryzu. Schorzenie to było zaliczane do somatycznych chorób urojeniowych. Clark i Simmons ${ }^{11}$ podtrzymywali teorię określoną przez Marbacha ${ }^{1}$ i podkreślali wpływ zaburzeń somatycznych na powstanie dyzestezji. Inni autorzy poddawali w wątpliwość jej słuszność, gdyż badania Watanabe i wsp. wskazały, że u mniej niż 50\%pacjentów z dyzestezją okluzyjną były diagnozowane choroby psychiczne. ${ }^{12}$

Dalszy rozwój teorii etiologicznych wskazał na możliwość przeniesienia do stomatologii teorii o neuro-podpisie (ang. neurosignature), znajdującym się w matrycy neuronów centralnego układu nerwowego, który zawiera informacje o całym organizmie. ${ }^{2}$ Gdy neuro-podpis zwarcia pacjenta nie zgadza się z informacją o zgryzie zmodyfikowanym leczeniem stomatologicznym, to może prowadzić do objawów dyzestezji okluzyjnej u osób z pewnymi predyspozycjami. Jest to porównywalne z bólem fantomowym amputowanej kończyny i brakiem adaptacji do protez. Podobnie w stomatologii, kiedy nowe kontakty okluzyjne nie są rozpoznawane jako „własny zgryz”.

Kolejna teoria etiologiczna zaproponowana przez Clark'a i Simmons 'a ${ }^{11}$ wskazuje na zaburzoną propriocepcję. Mówi ona o tym, że 
show a statistically significant difference in the recognition of particle size by people with dysesthesia and healthy individuals. It seems, therefore, that people with dysesthesia do not have an increased sensitivity of proprioceptors, but rather an incorrect interpretation of normal occlusal stimuli may be the case.

The main symptoms of dysesthesia focus on discomfort associated with occlusion, 1,3 which is usually associated with emotional suffering. Patients report that it is "not their bite", that previously "it was normal, not consciously perceived", and now "the mandible is constantly looking for the right position". Patients may talk for hours on end detailing earlier dental treatment, which did not bring improvement, comparing the shape and size of previous and present teeth, supporting their words with additional tests, models, occlusal splints. Often this narrative is accompanied by complaints about previous dentists, irritation associated with failure to solve their problem. Very often these symptoms coexist with other ailments, such as dysfunction of the motor system of the masticatory organ, bruxism, depression or somatic diseases, which further complicates diagnosis and treatment. This is especially evident in cases of concomitant temporomandibular disorders, the therapy of which is often based on the use of occlusal splints, and involves corrections and reconstruction of the occlusion. Their implementation worsens the symptoms of dysesthesia. Frequently, the symptoms of dysesthesia are recognized as symptoms of functional disorders, resulting in unnecessary treatment.

For these reasons, a meticulous clinical examination is particularly important, especially an interview where the affirmative answer to the question "Have you ever had a problem with your bite, which was uncomfortable?" should alert the doctor and influence further actions. Diagnostic criteria that allow diagnosing occlusal dysesthesia zmieniona pozycja żuchwy zmienia możliwość rozróżniania cząstek między zębami. Jednakże, wyniki badań innych autorów ${ }^{6,7}$ nie wykazują różnicy istotnej statystycznie w rozpoznawaniu wielkości cząstek przez osoby z dyzestezją a osoby zdrowe. Wydaje się więc, że u osób z dyzestezją nie występuje zwiększona czułość proprioceptorów, ale raczej można mieć do czynienia z nieprawidłową interpretacją normalnych bodźców zwarciowych.

Główne objawy dyzestezji ogniskują się wokół dyskomfortu związanego ze zgryzem, ${ }^{1,3}$ który zwykle połączony jest $\mathrm{z}$ cierpieniem emocjonalnym. Pacjenci podają, że to jest „nie ich zgryz”, że „wcześniej był normalny, nieodczuwalny”, a obecnie ,ciągle żuchwa szuka prawidłowej pozycji”. Bardzo wiele czasu zajmuje pacjentom opowiadanie o wcześniejszym leczeniu stomatologicznym, które nie przyniosło poprawy, z wieloma szczegółami, porównywaniem kształtu i wielkości wcześniejszych i obecnych zębów, poparciem swoich słów badaniami dodatkowymi, modelami, wieloma szynami zgryzowymi. Często temu opowiadaniu towarzyszy uskarżanie się na poprzednich stomatologów, irytacja związana $\mathrm{z}$ brakiem rozwiązania przez nich problemu. Bardzo często objawy te współistnieją z innymi dolegliwościami, takimi jak dysfunkcje układu ruchowego narządu żucia, bruksizm, depresja czy choroby somatyczne, co dodatkowo utrudnia rozpoznanie i leczenie. Szczególnie jest to dostrzegalne w przypadku równoległego występowania schorzeń skroniowo-żuchwowych, których terapia niejednokrotnie opiera się na zastosowaniu szyn zgryzowych, korekt i rekonstrukcji zwarcia, a ich wdrożenie pogarsza objawy dyzestezji. Niejednokrotnie też objawy dyzestezji rozpoznawane są jako objawy zaburzeń czynnościowych, co skutkuje niepotrzebnym leczeniem.

Z tych powodów tak ważne jest skrupulatne badanie kliniczne, a szczególnie wywiad, gdzie już twierdząca odpowiedź na pytanie: 
include: continuous discomfort associated with uncomfortable occlusion, lasting for more than six months; subjective symptoms that are not reflected by the physical examination of teeth, periodontium, masticatory muscles and temporomandibular joints; chronic but low level pain sensations, symptoms that are the cause of anguish and the reason for seeking further dental treatment. ${ }^{3}$ Unfortunately, except for the patient's complaint of "uncomfortable" bite, the other symptoms are non-specific. However, it should be added that these patients are characterized by emotional stress and even suffering-symptoms of other somatic diseases can be diagnosed.

Treatment of symptoms of dysesthesia is "no treatment". 1,3,13 Correction and attempt to achieve an "ideal" occlusion should be avoided. Management should include patient education, psychotherapy, the use of relaxation occlusal splints and the implementation of pharmacotherapy. Literature reports indicate changes in the nervous system centers related to the subjective perception of occlusion in people with occlusal dysesthesia, which means that dental treatment will not bring relief.

A focused interview should be considered and the use of tests recommended, for example, in the second axis of the research criteria for functional disorders of the masticatory organ (Diagnostic Criteria for Temporomandibular Disorders, DC/TMD). ${ }^{14-16}$ Interview and psychological tests will allow identification of patients with inclinations or even psychological disorders and somatic diseases, which is of great importance for the adaptation of future dental treatment.

\section{Summary}

It is difficult to distinguish between adapted habitual and pathological occlusion. In occlusal contacts, it is always possible to see the need for correction to improve the static and dynamic „czy kiedykolwiek miałeś problem ze swoim zgryzem, który był niekomfortowy?", powinno zwrócić uwagę lekarza i wpłynąć na jego dalsze postępowanie. Kryteria diagnostyczne, które umożliwiają rozpoznanie dyzestezji okluzyjnej to: ciągłe dolegliwości związane z niekomfortowym zgryzem, trwające dłużej niż 6 miesięcy; subiektywne objawy, które nie korespondują z badaniem przedmiotowym zębów, przyzębia, mięśni żucia i stawów skroniowo-żuchwowych; przewlekłe objawy bólowe, ale o niskim poziomie; objawy, które są powodem cierpienia i przyczyną poszukiwania dalszego leczenia stomatologicznego. ${ }^{3} \mathrm{Z}$ wyjątkiem relacji pacjenta o ,niekomfortowym” zgryzie, pozostałe objawy są jednak niespecyficzne. Należy dodać, że pacjentów tych charakteryzuje często emocjonalny stres i wręcz cierpienie, można także u nich stwierdzić objawy innych chorób somatycznych.

Leczeniem objawów dyzestezji jest „brak leczenia". 1,3,13 Należy unikać korekty i próby osiągnięcia ,idealnego" zwarcia. Postępowanie lecznicze powinno obejmować edukację pacjenta, psychoterapię, zastosowanie relaksacyjnych szyn zgryzowych i wdrożenie farmakoterapii. Doniesienia piśmiennictwa wskazują bowiem na zmiany w ośrodkach układu nerwowego związane z subiektywnym odczuwaniem zgryzu u osób z dyzestezją okluzyjną, co powoduje, że leczeniem stomatologicznym nie osiągnie się ustąpienia dolegliwości.

Warto zwrócić uwagę na ukierunkowany wywiad oraz zastosowanie testów zalecanych na przykład w II osi kryteriów badawczych dla zaburzeń czynnościowych narządu żucia (ang. Diagnostic Criteria for Temporomandibular Disorders, DC/TMD). ${ }^{14-16}$ Wywiad oraz testy psychologiczne pozwolą wyłonić pacjentów ze skłonnościami lub wręcz zaburzeniami psychologicznymi i chorobami somatycznymi, co ma ogromne znaczenie $\mathrm{w}$ adaptacji przyszłego leczenia stomatologicznego. 
occlusion in a specific position of the mandible. In particular, when there is a strong suggestion from the patient that "this is not their bite". With many adjustments it is easy to fall into a vicious circle and endless correction of the occlusion. For this reason, it is important to confirm the correctness of the bite and the patient's subjective complaints should be focused on the right problem. Non-invasive dental treatment, patient education and the ability to indicate the help of a psychotherapist are indispensable in such cases.

\section{Podsumowanie}

Należy stwierdzić, że w praktyce trudno jest odróżnić zwarcie nawykowe zaadaptowane od patologicznego i to może skutkować częstością zbędnych korekt. Szczególnie, gdy występuje silna sugestia pacjenta, że ,to nie jest jego zgryz". Wieloma korektami łatwo można wpaść w błędne koło i niekończące się wizyty. Z tego względu ważne jest stwierdzenie poprawności zgryzu a leczenie subiektywnych dolegliwości pacjenta należy ukierunkować na właściwy problem. W tego typu przypadkach nieodzowne są: nieinwazyjne leczenie stomatologiczne, edukacja pacjenta i umiejętność wskazania pomocy psychoterapeuty.

\section{References / Piśmiennictwo}

1. Marbach JJ: Phantom bite. Am J Orthod 1976; 70: 190-199.

2. Marbach JJ: Orofacial phantom pain: theory and phenomenology. J Am Dent Assoc 1996; 127: 221-229.

3. Hara ES, Matsuka Y, Minakuchi H, Clark GT, Kuboki T: Occlusal dysesthesia: a qualitative systematic review of the epidemiology, aetiology and management. J Oral Rehabil 2012; 39: 630-638.

4. Shetti SS, Chougule K: Phantom bite - a case report of a rare entity. J Dent Allied Sci 2012; 1: 82-84.

5. Reeves JL 2nd, Merrlill RL: Diagnostic and treatment challenges in occlusal dysesthesia. J Calif Dent Assoc 2007; 35: 198-207.

6. Tsukiyama Y, Yamada A, Kuwatsuru $R$, Koyano K: Bio-psycho-social assessment of occlusal dysaesthesia patients. J Oral Rehabil 2012; 39(8): 623-629. doi: 10.1111/j.13652842.2012.02317.

7. Oguchi H, Yamauchi Y, Karube Y, Suzuki N, Tamaki K: Occlusal dysesthesia: A clinical report on the psychosomatic management of a Japanese patient cohort. Int J Prosthodont 2017; 30(2): 142-146. DOI: 10.11607/ ijp. 4833

8. Narita N, Kamiya K, Makiyama Y, Iwaki S, Komiyama O, Ishii T, Wake $H$ : Prefrontal modulation during chewing performance in occlusal dysesthesia patients: a functional near-infrared spectroscopy study. Clin Oral Invest 2018, 1-16. Article in Press. DOI: 10.1007/s00784-018-2534-7

9. Ono Y, Ishikawa Y, Munakata M, Shibuya T, Shimada A, Miyachi H, Wake H, Tamaki K: Diagnosis of occlusal dysesthesia utilizing prefrontal hemodynamic activity with slight occlusal interference. Clin Exp Dent Res 2016; 2(2): 129-135. DOI: 10.1002/cre2.32

10. Baba K, Aridome K, Haketa T, Kino K, Ohyama $T$ : Sensory perceptive and discriminative abilities of patients with occlusal dysesthesia. J Jpn Prosthodon Soc 2005; 49: 599-607.

11. Clark G, Simmons M: Occlusal dysesthesia and temporomandibular disorders: is there a 
link? (2003) Alpha Omegan 2013; 96(2): 3339.

12. Watanabe M, Umezaki Y, Suzuki S, Miura A, Shinohara Y, Yoshikawa T, et al.: Psychiatric comorbidities and psychopharmacological outcomes of phantom bite syndrome. J Psychosom Res 2015; 78: 255-259.

13. Melis M, Zawawi KH: Occlusal dysestesia: a topical narrative review. J Oral Rehabil 2015; 42: 779-785.

14. Dworkin SF, Le Resche L: Research diagnostic criteria for temporomandibular disorders: review, criteria, examinations and specifications, critique. J Craniomand Dis Facial \& Oral Pain 1992; 6, 4: 301-355.

15. Osiewicz M, Lobbezoo F, Loster BW, Wilkosz $M$, Naeije M, Orbach R: Research Diagnostic
Criteria for temporomandibular Disorders (RDC/TMD): The Polish version of a dualaxis system for TMD diagnosis. Protet Stomatol 2010; LX, 6: 433-444.

16. Schiffman E, Ohrbach $R$, Truelove E, Look J, Anderson G, Goulet JP, et al.: Diagnostic Criteria for Temporomandibular Disorders (DC/TMD) for Clinical and Research Applications: recommendations of the International RDC/TMD Consortium Network and Orofacial Pain Special Interest Group. J Oral Facial Pain Headache 2014; 28: 6-27.

Zaakceptowano do druku: 9.01.2020 r.

Adres autora: 02-097 Warszawa, ul. Binieckiego 6.

(C) Zarząd Główny PTS 2020. 